\title{
Overview of Macro Nutrient Intake and Nutritional Status of Students at the Putri Hidayatullah Islamic Boarding School, Ternate City
}

\author{
Hisdawati Abubakar ${ }^{1}$, Yohannes Willi Helm ${ }^{1}$, Nofiandri ${ }^{2}$ Fadila $^{3}$ \\ ${ }^{12}$ Jurusan Gizi, Poltekkes Kemenkes Ternate, Indonesia
}

\begin{abstract}
Adolescents are one of the nutritionally vulnerable groups. At this time, adolescents enter the second phase of rapid growth and then physical growth declines as young adults enter. Problems that arise in adolescents are undernutrition and overnutrition. One that is related to nutritional status is nutrient intake which is very influential on a person's nutritional status. Nutrient intake is influenced by eating habits and eating patterns of adolescents themselves. The purpose of this study was to determine the description of macronutrient intake and nutritional status at the Putri Hidayatullah Islamic Boarding School, Ternate City. The type of research used is descriptive research. The sampling technique used total sampling with a total sample of 29 people. The tools used were Microtoise, Bathroom Scale and form food recall 24. The results showed that the intake of macronutrients, as many as 28 people (96.6\%) with less energy intake, 29 people $(100.0 \%)$ with less protein intake, 16 people $(55.2 \%)$ with more fat intake and 26 people $(89.7 \%)$ with less carbohydrate intake. There were 25 people $(86.2 \%)$ with normal nutritional status. It was concluded that from the results of the respondents had less protein intake and most had less energy and carbohydrate intake. On the other hand, most of these teenagers have good fat intake with normal nutritional status.
\end{abstract}

\section{Introduction}

Adolescents are one of the vulnerable groups for nutrition. At this time, adolescents enter the second phase of rapid growth and then physical growth declines as young adults enter. Therefore, teenagers need adequate food, not only in terms of quantity but also in terms of quality. The more varied or varied the foods consumed by adolescents will be guaranteed the fulfillment of nutritional adequacy which in turn will have an impact on their nutritional and health status(Azrimaidaliza \& Purnakarya, 2011)

The nutritional status of adolescents is very important to support their growth and development. Optimal nutritional status will form a healthy and productive teenager. The problems that arise are undernutrition and overnutrition. Malnutrition can lead to a decrease in academic achievement and result in reproductive system disorders that have a bad impact later on(Zuhdy, 2015). Undernutrition occurs because the amount of energy consumption and other nutrients does not meet the body's needs, while the incidence of overnutrition is caused by poor food habits so that the amount of energy input is excessive(Supariasa, 2010).

The nutritional status of adolescents is influenced by various factors (multifactoral). One that relates to nutritional status is nutrient intake which greatly influences a person's nutritional status. Nutrient intake is influenced by eating habits and eating patterns of adolescents themselves. Eating habits acquired in adolescence will have an impact on health in later life(Sulistyoningsih, 2012).

Macronutrients are nutrients that are important for a person in carrying out activities, maintaining the body, repairing damaged muscles and tissues. Intake of protein, fat, and carbohydrates in metabolism will produce energy used for daily activities. Proteins contained in foodstuffs after consumption will undergo a breakdown (hydrolysis by protease enzymes) into their constituent units, namely amino acids. Fats are organic compounds that are soluble in alcohol and other organic solutions, but insoluble in water and carbohydrates are the main source of energy for the body compared to proteins and fats. Macronutrient intake is closely related to nutritional status because macronutrients can produce energy to meet needs, so 
that if there is an imbalance in the level of adequacy of macronutrients, it can cause nutritional problems(Supariasa, 2010).

Based on data from Riskesdas (2018), thin children reached $8.9 \%$ and overweight children reached $1.4 \%$. In North Maluku, the nutritional status of adolescents according to the BMI/U category was found to be $1.2 \%$ very thin, 3.9\% normal and $6.0 \%$ fat. Judging from the large number of nutritional problems in adolescents in Indonesia, especially North Maluku Province so far there are still adolescent nutritional problems.

Putri Hidayatullah Islamic Boarding School is one of the educational institutions that provides meals during education. The provision of food is managed by the Islamic boarding school itself without interference from outside parties such as catering. Santriwati (student) at the Hidayatullah Islamic Boarding School is classified as a teenager so that it is still in the stage of growth and development. Therefore, it is very important to pay attention to the adequacy of food intake in terms of quality and quantity for young women at the Hidayatullah Islamic Boarding School.

Based on the description above, researchers are interested in researching macronutrient intake and nutritional status in the Hidayatullah Islamic Boarding School in Ternate City because the nutritional status of adolescents is influenced by various factors, one of which is the intake of macronutrients. teenagers and also no one has researched in that place.

\section{Method}

This type of research is descriptive with a cross sectional research design, namely by examining the independent and dependent variables simultaneously.

1. Population

The population in this study were all high school students of class $\mathrm{X}$ who lived in the Hidayatullah female Islamic boarding school in Ternate, which amounted to 32 people.

\section{Sample}

The sample used in this study were some of the class $\mathrm{X}$ students who were taken using a purposive sampling technique, which is a sampling technique based on certain considerations of researchers based on meeting information needs(Sugiyono, 2011). The sample size in this study amounted to 32 people. The sample inclusion criteria used in this study were:

a. Class X high school student.

b. Willing to be a research sample.

c. Lives in a boarding school.

The sample exclusion criteria used are:

a. At the time of the study the sample did not respond (indifference).

b. At the time of the study the sample was sick.

c. At the time of the study the respondent was not in place.

\section{Results and Discussion}

\section{a. Results}

\section{Overview of Research Sites}

The Hidayatullah Islamic Boarding School in Ternate is one of the branches of the Hidayatullah Islamic Boarding School which is spread across several provinces in Indonesia. The name Hidayatullah is taken from an Islamic mass organization (ormas) in Indonesia, the name comes from two Arabic words, namely Hidayat / Hidayah and Allah which means God's guidance. Hidayatullah Islamic Boarding School was founded on January 7, 1973 in Balikpapan in the form of a pesantren by Ust. Abdullah Said (late), then developed with various business charities in the social, da'wah, education and economic fields and spread to various regions in all provinces in Indonesia.

The purpose of the establishment of the Hidayatullah Islamic Boarding School in Ternate City as a place to explore religious knowledge for elementary, middle and high school children. This Islamic boarding school is divided into two, namely women's boarding schools and male boarding schools which are inhabited by students, teachers, caregivers, managers and Hidayatullah congregation. Santri who are in Islamic boarding 
schools are students who are basically the same as students in public schools. The organization of institutional food at the Hidayatullah Islamic Boarding School is managed by the Islamic Boarding School itself, this makes it easier for students to meet their food needs.

The source of funding for the provision of food is from the monthly payment of SP students. In general, Hidayatullah educational institutions include kindergartens and playgroups for Pre-School, Elementary School or Madrasah Ibtidaiyah, Junior High School or Madrasah Aliyah in almost all regions and in 2013.

\section{General Characteristics of Respondents}

Respondents in this study were aged 14 to 16 years. The characteristics of respondents by age can be seen in table 1.

Table 1. Distribution of Respondents by Age in Young Women at the Hidayatullah Islamic Boarding School, Ternate City in 2020

\section{Source: Primary Data, 2020}

\begin{tabular}{|c|c|c|}
\hline Age & $\mathbf{n}$ & $\mathbf{\%}$ \\
\hline 14 years & 10 & 34.5 \\
\hline 15 years & 17 & 58.6 \\
\hline 16 years & 2 & 6.9 \\
\hline Total & $\mathbf{2 9}$ & $\mathbf{1 0 0 . 0}$ \\
\hline
\end{tabular}

Based on table 1, it shows that the highest number of respondents was at the age of 15 years as many as 17 people (58.6\%) and the lowest was at the age of 16 years as many as 2 people (6.9\%).

\section{Intake of Macro Nutrients}

The intake of macronutrients obtained in this study was presented based on the type of intake, namely energy, protein, fat and carbohydrates. Distribution of respondents based on macronutrient intake can be seen in table 2 .

Table 2. Distribution of Respondents Based on Macro Nutrient Intake in Young Women at Hidayatullah Islamic Boarding School Ternate City in 2020

\begin{tabular}{|l|c|c|c|c|}
\hline $\begin{array}{c}\text { Intake } \\
\text { of } \\
\text { Macro } \\
\text { Nutrient } \\
\mathrm{s}\end{array}$ & Less & $\begin{array}{c}\text { Goo } \\
\mathrm{d}\end{array}$ & Over & $\begin{array}{c}\text { Tota } \\
1\end{array}$ \\
\hline $\begin{array}{l}\text { Energy } \\
\text { (Kkal) }\end{array}$ & $\begin{array}{c}28 \\
(96, \\
6)\end{array}$ & $\begin{array}{c}1 \\
(3,4)\end{array}$ & $\begin{array}{c}0 \\
(0,0)\end{array}$ & $\begin{array}{c}29 \\
(100 \\
, 0)\end{array}$ \\
\hline $\begin{array}{l}\text { Protein } \\
\text { (gram) }\end{array}$ & $\begin{array}{c}29 \\
(100\end{array}$ & 0 & 0 & 29 \\
$(0,0)$ & $(0,0)$ & $(100$ \\
& $0)$ & & & $0)$ \\
\hline $\begin{array}{l}\text { Fat } \\
\text { gram) }\end{array}$ & $\begin{array}{c}10 \\
(34,\end{array}$ & $\begin{array}{c}16 \\
(55,\end{array}$ & $\begin{array}{c}3 \\
(10,\end{array}$ & $\begin{array}{c}29 \\
(100 \\
, 0)\end{array}$ \\
\hline $\begin{array}{l}\text { Carboh } \\
\text { ydrate } \\
\text { (gram) }\end{array}$ & $\begin{array}{c}26 \\
(89,\end{array}$ & $\begin{array}{c}3 \\
(10,\end{array}$ & $\begin{array}{c}0 \\
(0,0)\end{array}$ & $\begin{array}{c}29 \\
(100 \\
, 0)\end{array}$ \\
\hline
\end{tabular}

Source: Primary Data, 2020

Based on table 2, it can be seen that the respondents with less energy intake were 28 people $(96.6 \%)$ and the respondents with good energy intake were 1 person $(3.4 \%)$. When viewed from the intake of protein nutrients, all respondents have less protein intake 29 people $(100.0 \%)$. In terms of fat intake, respondents with good fat intake were 16 people $(55.2 \%)$, respondents with less fat intake were 10 people (34.5\%) and respondents with more fat intake were 3 people $(10.3 \%)$. And on carbohydrate intake, respondents with less 
carbohydrate intake were 26 people $(89.7 \%)$ and respondents with good carbohydrate intake were 3 $(10.3 \%)$.

\section{Nutritional Status}

The nutritional status obtained in this study is presented based on the results of calculations with reference to the nutritional status criteria, namely the status of undernourishment (thinness), good nutrition (normal), overweight (overweight) and obesity (obese). Distribution of Respondents Based on Nutritional Status $\mathrm{BMI} / \mathrm{U}$ can be seen in table

Table 3. Distribution of Respondents Based on Nutritional Status of BMI/U in Young Women at Hidayatullah Islamic Boarding School Ternate City in 2020

Source: Primary Data, 2020

\begin{tabular}{|l|c|c|}
\hline $\begin{array}{c}\text { Nutritional } \\
\text { Status IMT/U }\end{array}$ & $\mathbf{n}$ & $\mathbf{\%}$ \\
\hline Thinness & 1 & 3.4 \\
\hline Normal & 25 & 86.2 \\
\hline Overweight & 1 & 3.4 \\
\hline Obese & 2 & 6.9 \\
\hline Total & $\mathbf{2 9}$ & $\mathbf{1 0 0 . 0}$ \\
\hline
\end{tabular}

Based on table 3, it shows that most of the respondents with good nutrition (normal) are 25 people (86.2\%), respondents with obesity nutritional status (obese) 2 people $(6.9 \%)$, respondents with overweight status (overweight) 1 person $(3.4 \%)$ and 1 person $(3.4 \%)$.

\section{Distribution of Respondents Intake of Macro Nutrients Based on Nutritional Status}

Table 4. Distribution of Respondents' Macronutrient Intake Based on Nutritional Status in Adolescents at Hidayatullah Islamic Boarding School Ternate City in 2020

\begin{tabular}{|c|c|c|c|c|c|}
\hline \multirow{2}{*}{ Variable } & \multicolumn{4}{|c|}{ Nutritional Status } & \multirow[t]{2}{*}{ Total } \\
\hline & Thinness & Normal & Overweight & Obese & \\
\hline $\begin{array}{l}\text { Energy Intake } \\
\text { is Not Good }\end{array}$ & $\begin{array}{l}1(3.5 \%) \\
0(0.0 \%)\end{array}$ & $\begin{array}{l}24(85.7 \\
\%) \\
1(100 \%)\end{array}$ & $\begin{array}{l}1(3.5 \%) \\
0(0.0 \%)\end{array}$ & $\begin{array}{l}2(7.1 \%) \\
0(0.0 \%)\end{array}$ & $\begin{array}{r}28(100 \%) \\
1(100 \%)\end{array}$ \\
\hline $\begin{array}{ll}\text { Less } & \text { Protein } \\
\text { Intake } & \end{array}$ & $1(3.4 \%)$ & $\begin{array}{c}25(86.2 \\
\%)\end{array}$ & $1(3.4 \%)$ & $2(7.1 \%)$ & $29(100 \%)$ \\
\hline $\begin{array}{l}\text { Less Good Fat } \\
\text { Intake More }\end{array}$ & $\begin{array}{l}1(10 \%) \\
0(0.0 \%) \\
0(0.0 \%)\end{array}$ & $\begin{array}{c}8(80 \%) \\
14(87.5 \\
\%) \\
3(100 \%)\end{array}$ & $\begin{array}{c}0(0.0 \%) \\
1(6.2 \%) \\
0(0.0 \%)\end{array}$ & $\begin{array}{l}1(10 \%) \\
1(6.2 \%) \\
0(0.0 \%)\end{array}$ & $\begin{array}{c}10(100 \%) \\
16(100 \%) \\
3(100 \%)\end{array}$ \\
\hline $\begin{array}{l}\text { Carbohydrate } \\
\text { intake is not } \\
\text { good }\end{array}$ & $\begin{array}{l}1(3.8 \%) \\
0(0.0 \%)\end{array}$ & $\begin{array}{l}23(88.4 \\
\%) \\
2(66.6 \% \\
0\end{array}$ & $\begin{array}{l}1(3.8 \%) \\
0(0.0 \%)\end{array}$ & $\begin{array}{l}1(3.8 \%) \\
1(33.3 \%)\end{array}$ & $\begin{array}{l}26(100 \%) \\
3(100 \%)\end{array}$ \\
\hline
\end{tabular}

Source: Primary Data, 2020 
Based on table 4, it shows that respondents who have less energy intake with less nutritional status are 1 person $(3.5 \%)$, less energy intake with good nutritional status 24 people $(85.7 \%)$, less energy intake with more nutritional status 1 person ( $3.5 \%$ ), less energy intake with obesity nutritional status 2 people (7.1 $\%)$, good energy intake with good nutritional status 1 person (100\%). Respondents who have less protein intake with less nutritional status 1 person $(3.4 \%)$, less protein intake with more nutritional status 25 people $(86.2 \%)$, less protein intake with more nutritional status 1 person $(3.4 \%)$, respondents who have less protein intake with obesity nutritional status 2 people $(7.1 \%)$.

Respondents who have less fat intake with less nutritional status 1 person (10\%), less fat intake with good nutritional status 8 people $(80 \%)$, less fat intake with obesity nutritional status 1 person (10\%), good fat intake with nutritional status good nutrition 14 people $(87.5 \%)$, good fat intake with more nutritional status 1 person $(6.2 \%)$, good fat intake with obesity nutritional status 1 person $(6.2 \%)$ more fat intake with good nutritional status 3 people $(100 \%)$.

Respondents who have less carbohydrate intake with less nutritional status 1 person (3.8\%), less carbohydrate intake with good nutritional status 23 people $(88.4 \%)$, less carbohydrate intake with more nutritional status 1 (3.8\%), low carbohydrate intake with obesity nutritional status 1 person (3.8 \%), good carbohydrate intake with good nutritional status 2 people $(66.6 \%)$, good carbohydrate intake with obesity nutritional status 1 person $(33.3 \%)$.

\section{b. Discussion}

\section{Intake Macro Nutrients}

a) Energy

Energy is needed by the body for the continuity of processes in the body such as circulation and circulation in the blood, heart rate, respiration, digestion, to move or do physical work. Energy comes from carbohydrates, proteins and fats, therefore for sufficient energy it is necessary to consume sufficient and balanced food(Gandy, Madden, \& Holdsworh, 2014).

Consumption of energy and nutrients is influenced by age, weight, height, eating patterns and habits, and income. Energy in the human body can arise due to the burning of carbohydrates, proteins, and fats. energy sufficiency(Achadi, 2010).

Based on the results of the study, it is known that 28 respondents have less energy intake. This is because the food administration system at the Hidayatullah Islamic Boarding School does not use nutritionists and also does not allow students to take their own food so that the portion of food provided by the presenter is still less than what is needed, judging by the results of the 24-hour recall of carbohydrate-source foods that have not met the respondents' carbohydrate needs, there are also respondents who skip meals because they are late when the meal schedule arrives and run out of food, the menus served are not updated, it may be due to the fact that the costs provided for the procurement of food ingredients are not sufficient for holding a new menu because at the time of research on food ingredients, especially animal side dishes in the form of medium fish expensive.

The results of research conducted by Amelia, Syam, and Fatima (2013), in adolescent boarding schools, the results obtained were $87 \%$ of respondents with less energy intake and $13 \%$ with sufficient energy intake. This shows that the percentage of food intake, especially energy intake consumed by young women is still very low.

Unmet nutritional needs can cause nutritional problems, especially for adolescents because it can have a negative impact, malnutrition in adolescents causes a decrease in learning concentration and a decrease in physical fitness(Almatsier, 2010).

\section{b) Protein}


Protein is one of the macronutrients that are important for human life in addition to carbohydrates and fats. In general, protein functions for growth, formation of structural components, transport and storage of nutrients, enzymes, antibody formation and energy sources(Hardinsyah \& Supariasa, 2016).

If energy intake is lacking for various reasons, protein intake will be used to meet energy needs, so that there may not be enough protein available in the formation of new tissue or to repair damaged tissue. This can lead to a reduction in the rate of growth and a decrease in body muscle mass(Almatsier, 2010).

The results in this study indicate that of all respondents, which amounted to 29 people, 29 people had less protein intake $(100.0 \%)$. This is because at the time of the study the respondents consumed small amounts of protein source foods, namely $30 \mathrm{~g}$ in one meal and were less diverse due to the costs provided for the procurement of protein source foods, which at the time of the study of food ingredients, especially animal side dishes in the form of fish, were expensive so the amount of protein intake is not sufficient for adequate protein intake.

The results of research conducted by Sofiatun, Manti, and Indiasari (2017), in adolescents on Barrang Lompo Island, Sengkarrang District, Makassar, the results showed that students whose protein intake was in the less category were 72 people $(87.8 \%)$ which means protein intake in adolescents is still not sufficient.

The need for protein nutrients that are not fulfilled will have an impact on hair loss, impaired brain function and mental health, decreased body immunity, stunted growth and development of children and slow wound healing process(Almatsier, 2010).

\section{c) Fat}

Fats (lipids) are hydrophobic organic substances that are poorly soluble in water. Fat is a substance that is rich in energy and serves as an energy source that has an important role in the process of fat metabolism(Hardinsyah \& Supariasa, 2016).

Fat is a stored source of essential nutrients. The function of fat itself is as the most dense source of energy which produces $9 \mathrm{kcal}$ per gram. Fat intake that exceeds needs in the long term can trigger overweight.

The results in this study indicate that of all respondents, amounting to 29 people, 16 people (55.2\%) had good fat intake, 10 respondents with less fat intake (34.5\%) and 3 respondents with more fat intake $(10.3 \%)$.

From the results of interviews with respondents, the lack of fat intake is due to the frequency of eating in consuming foods that are sources of fat, so that respondents are still lacking so that they have not been able to meet the respondent's fat needs. As for the higher fat intake, the respondents consumed a lot of snacks with high fat content, such as fried foods.

The results of research conducted by Muchlisa and Indiasari (2013), on Young Women at the Faculty of Public Health, Hasanuddin University Makassar, the results showed that adequate fat intake was 96.9\%, while respondents who had less fat intake were only $3.1 \%$. This shows that most of the respondents have sufficient fat intake.

Lack of intake of fat nutrients will experience the risk of vitamin deficiency, often feel cold, heart and blood vessel health problems, impaired fertility, tired and hungry(Almatsier, 2010)

\section{d) Carbohidrat}

Humans eat food for survival. Every food consumed daily contains nutrients that vary, both in type and amount. Among the nutrients that the body needs, as the body's main source of energy, it is obtained from carbohydrates. Carbohydrates are the fastest food substances to supply energy as fuel for the body. After 
foods containing carbohydrates are consumed, the carbohydrates are immediately oxidized to meet energy needs(Hardinsyah \& Supariasa, 2016).

Carbohydrates are one of the important nutrients that provide large enough energy for the body to work and function properly. Carbohydrate consumption must be balanced between energy intake and expenditure, if the intake is more than the expenditure, the energy that is not used will be stored in the body in the form of fat, as a result many people become obese due to excess energy and will continue with the emergence of health problems(Graha, 2010).

The results in this study indicate that of all respondents, which amounted to 29 people, 26 people $(89.7 \%)$ had less carbohydrate intake and 3 respondents with good carbohydrate intake (10.3\%). consumed by respondents did not match their needs, this is because the food administration system at the Hidayatullah Islamic Boarding School does not use nutritionists so that the portion of food provided is not in accordance with needs.

The results of research conducted by Nova and Yanti (2018) on students of MTs.S An-Nur Padang City, based on the results of the study showed that the carbohydrate intake of 57 respondents in MTs.S AN-NUR Padang City was $(94.7 \%)$ who have sufficient carbohydrate intake and $(5.3 \%)$ who have less carbohydrate intake. This means that most of the respondents have sufficient carbohydrate intake.

Lack of intake of carbohydrate nutrients can have an impact, namely ketosis which is a condition when the body uses fat as an energy source, lacks energy, damages blood vessels, increases the risk of getting cancer and decreases body weight(Almatsier, 2010).

\section{Nutritional Status}

Nutritional status is an expression of a state of balance in the form of certain variables or it can be said that nutritional status is an indicator of whether or not the daily food supply is good or bad. Good nutritional status is needed to maintain health status, help growth for children's growth(Supariasa, 2010).

According to Almatsier (2010), each person requires different amounts of food (nutrients), depending on age, weight, height, gender, physical activity and environmental conditions. A child in his growth period requires balanced nutrition for growth and development compared to adults.

Food consumption affects a person's nutritional status. Good nutritional status or optimal nutritional status occurs when the body gets enough nutrients that are used efficiently, thus allowing physical growth, brain development, work ability, and general health at the highest possible level. Nutritional problems can occur because a person lacks one or more nutrients in the body(Almatsier, 2010).

Based on the results of research on respondents conducted through anthropometric measurements, namely Height and Weight, data obtained that there are 4 categories obtained by respondents, namely poor nutritional status, good nutrition, overweight and obesity. Respondents with good nutrition (normal) as many as 25 people $(86.2 \%)$, respondents with obesity nutritional status (obese) 2 people $(6.9 \%)$, respondents with overweight status (overweight) 1 person (3.4\%) and respondents with less nutrition ( thinness) 1 person (3.4 $\%)$. This nutritional status is a description of food intake (input) and activity (output).

The data above shows that the nutritional status of the students at the Hidayatullah Islamic Boarding School which was the sample in this study did not have serious problems in terms of nutritional status but what should be paid more attention to are respondents who have less nutritional status, overweight and obesity because although the numbers are small when compared with normal nutritional status will have a negative impact.

This proves that the intake of macronutrients taken from the results of the $3 \times 24$ hour food recall of the respondents does not affect the nutritional status because the recording of food cannot describe the nutritional status in the long term due to anthropometric measurements that are carried out only once and 
also no monitoring of anthropometric measurements is carried out. continuously. This is also indicated by the results of macronutrient intake based on BMI/U nutritional status which shows that most of the respondents who have less macronutrient intake but have good nutritional status.

This situation is almost the same as the research conducted by Makalew, Kawengian, and Malonda (2013). The results of research that has been carried out on elementary school children in West Langowan District show the relationship between energy intake and BMI/U with the level of energy intake over normal nutritional status of $7.1 \%$ and nutritional status of obesity by $2.9 \%$. The level of energy intake is sufficient for obesity nutritional status of $5.7 \%$, obese nutritional status of $7.1 \%$ and normal nutritional status of $44.3 \%$. The level of low energy intake with normal nutritional status is $32.9 \%$. There is no significant relationship between energy intake and nutritional status (W/U, TB/U and BMI/U), but there is a significant relationship between energy intake and BW/TB. Contrary to Setiyaningrum (2017), that there is a relationship between the level of energy consumption with nutritional status and there are other factors that influence nutritional status, namely maternal behavior. Sulistya (2013) in their research, that there is no significant relationship between energy intake and poor nutritional status. This study agrees with (Nur'aini \& Wiyono, 2012), that there is no relationship between nutritional status and energy intake.

The relationship between protein intake and $\mathrm{BMI} / \mathrm{U}$ with more protein intake, normal nutritional status was $40 \%$, obese nutritional status was $1.4 \%$ and obesity nutritional status was $4.3 \%$. The level of adequate protein intake with obesity nutritional status is $2.9 \%$, obese nutritional status is $5.7 \%$ and normal nutritional status is $38.6 \%$. The level of protein intake with normal nutritional status is $5.7 \%$ and obesity nutritional status is $1.4 \%$. There is no low level of protein intake with obese nutritional status, this proves that there is no relationship between protein intake and body mass index according to age.

According to Zulfa (2011) in his research there is a relationship between fast food consumption and nutritional status. Research conducted by Sumardilah, Masra, and Nugroho (2010) contradicts this study, that there is a significant relationship between energy and protein consumption and nutritional status. Fahmia, Mulyati, and Handarsari (2012) agree with Sumardilah et al, that there is a relationship between energy and protein intake and nutritional status, but their research was conducted on adults and this study on elementary school children. Purwaningrum and Wardani (2012) contradicts this study in their research that there is a relationship between food intake (energy and protein) with nutritional status, and there are other factors related to nutritional status, namely family nutritional awareness.

\section{Conclusion}

1. All young women in the Hidayatullah Islamic Boarding School in Ternate City have less protein intake and most of them have less energy and carbohydrate intake. On the other hand, most of these teenagers have good fat intake.

2. Nutritional status of adolescent girls at the Pondok Pesantren Putri Hidayatullah Ternate City mostly have good nutritional status (normal) as many as 25 people.

\section{Reference}

1. Achadi. (2010). Gizi dan Kesehatan Masyarakat, Departemen Gizi dan Kesehatan Masyarakat Universitas Indonesia (UI). Raja Grafindo Persada: Jakarta.

2. Almatsier, S. (2010). Prinsip Dasar Ilmu Gizi. Jakarta: Gramedia Pustaka Utama.

3. Amelia, A. R., Syam, A., \& Fatima, S. (2013). Hubungan Asupan Energi dan Zat Gizi Dengan Status Gizi Santri Putri Yayasan Pondok Pesantren Hidayatullah. Universitas Hasanuddin, Makassar

4. Azrimaidaliza, A., \& Purnakarya, I. (2011). Analisis Pemilihan Makanan pada Remaja di Kota Padang Sumatera Barat. Kesmas: Jurnal Kesehatan Masyarakat Nasional (National Public Health Journal), 6(1), 17-22.

5. Fahmia, N. I., Mulyati, T., \& Handarsari, E. (2012). Hubungan Asupan Energi dan Protein dengan Status Gizi pada Penderita Gagal Ginjal Kronik yang Menjalani Hemodialisa Rawat Jalan di RSUD Tugurejo Semarang. Jurnal Gizi, 1(1).

6. Gandy, Madden, A., \& Holdsworh, M. (2014). Gizi dan Dietetik. Jakarta: EGC. 
7. Graha, K. C. (2010). Kolestrol. Jakarta: PT Elex Media Komputindo.

8. Hardinsyah, \& Supariasa. (2016). Ilmu Gizi Teori dan Aplikasi. Jakarta: Buku Kedokteran EGC.

9. Makalew, Y. M., Kawengian, S. E., \& Malonda, N. S. (2013). Hubungan antara Asupan Energi dan Zat Gizi dengan Status Gizi Anak Sekolah dasar Kelas 4 dan Kelas 5 SDN 1 Tounelet dan SD Katolik St. Monica Kecamatan Langowan Barat Manado: Skripsi.

10. Muchlisa, \& Indiasari, R. (2013). Hubungan Asupan Zat Gizi Dengan Status Gizi Pada Remaja Putri. Universitas Hasanuddin, Makassar.

11. Nova, M., \& Yanti, R. (2018). Hubungan Asupan Zat Gizi Makro dan Pengetahuan Gizi dengan Status Gizi pada Siswa Mts. s An-nurkota Padang. JURNAL KESEHATAN PERINTIS (Perintis's Health Journal), 5(2), 169-175.

12. Nur'aini, F., \& Wiyono, S. (2012). Hubungan Antara Asupan Energi, Protein dan Infeksi Kecacingan dengan Status Gizi Anak Usia Sekolah Dasar di Daerah Kumuh Perkotaan RW 10 Kelurahan Angke Kecamatan Tambora Jakarta Barat. Jurnal Penelitian, 6(2).

13. Purwaningrum, S., \& Wardani, Y. (2012). Hubungan antara Asupan Makanan dan Status Kesadaran Gizi Keluarga dengan Status Gizi Balita di Wilayah Kerja Puskesmas Sewon I, Bantul. Jurnal Kesehatan Masyarakat, 6(3), 144-211.

14. Setiyaningrum, Z. (2017). Hubungan Asupan Energi dan Perilaku Hidup Bersih dan Sehat (PHBS) dengan Status Gizi Balita di Puskesmas Klego 1 Boyolali. Universitas Muhammadiyah Surakarta.

15. Sofiatun, T., Manti, S., \& Indiasari, R. (2017). Status Gizi, Asupan Zat Gizi Makro, Aktivitas Fisik, Pengetahuan dan Praktik Gizi Seimbang Pada Remaja Prodi Ilmu Gizi. Universitas Hasanuddin, Makassar.

16. Sugiyono. (2011). Metode Penelitian Kuantitatif, Kualitatif, dan R\&D. Bandung: Alfabeta.

17. Sulistya, K. (2013). Hubungan Tingkat Asupan Energi dan Protein Dengan Kejadian Gizi Kurang Anak Usia 2-5 Tahun. Jurnal Gizi, 2(1).

18. Sulistyoningsih, H. (2012). Gizi Untuk Kesehatan Ibu dan Anak. Jakarta: Graha Ilmu.

19. Sumardilah, D., Masra, F., \& Nugroho, A. (2010). Hubungan Tingkat Konsumsi Makanan dengan Status Gizi Siswa Sekolah Menengah Atas (SMA) Di Bandar Lampung Tahun 2009. Jurnal Kesehatan, 1(1).

20. Supariasa, I. D. N. (2010). Penilaian Status Gizi (Edisi Revisi). Jakarta: Buku Kedokteran EGC.

21. Zuhdy, N. (2015). Hubungan Pola Aktivitas Fisik dan Pola Makan dengan Status Gizi Pada Pelajar Putri SMA Kelas 1 Di Denpasar Utara. Universitas Udayana, Denpasar.

22. Zulfa, F. (2011). Hubungan Kebiasaan Konsumsi Fastfood Modern dengan Status Gizi (BB/TB ZScore) di SD Al-Muttaqin Tasikmalaya. Peran Kesehatan Masyarakat dalam Pencapaian MDG's di Indonesia. Prosiding, 12. 